\title{
A Better MLE Nitrification Process Adopted from STOAT Simulation Experiments
}

\author{
Taewook Kim $^{1 \oplus} \cdot$ Sunjoo Cho $^{1 \oplus} \cdot$ Sung-Hyun Kwon ${ }^{2 \odot} \cdot$ Daechul Cho $^{1,+\oplus}$ \\ 'Department of Energy\&Environmental Engineering, Soonchunhyang University \\ ${ }^{2}$ Department of Marine Environmental Engineering, Gyeongsang National University
}

(Received April 30, 2021; Revised June 3, 2021; Accepted June 4, 2021)

Objectives: Nitrogen removal processes are very important in terms of water conservation. Among them, the MLE process has been difficult to optimize because it has many variations and required experiences in operation.

Methods: In this work, we quantitatively analyzed the nitrification of the MLE process using the STOAT simulation program. In particular, we attempted to improve nitrification rate even at lower water temperatures.

Results and Discussion: As a result, more than 93\% ammonia was nitrificated when the water temperature was above $20^{\circ} \mathrm{C}$, and a lower reduction rate of ammonia was observed when the temperature was below $15^{\circ} \mathrm{C}$. Simulations applying three process variables (MLSS, DO concentration, and RAS) were carried out once or several times to increase nitrogen removal efficiency at $10^{\circ} \mathrm{C}$, and the most efficient variable was 'RAS increase' $(55 \%$ reduction of ammonia).

Conclusions: For more efficient nitrification rate, simultaneous increases in RAS and DO were required. In this case, the ammonia concentration in the effluent dropped by $61.4 \%$ and it was desirable to increase the MLSS return volume for T-N concentration reduction.

Keywords: Simulator, STOAT, Wastewater Treatment, Biological Treatment, MLE Process

The Korean text of this paper can be translated into multiple languages on the website of http://jksee.or.kr through Google Translator.

\footnotetext{
Corresponding author

E-mail: lafcho@naver.com

Tel: 041-530-1341 Fax: 041-530-1659

(c) 2021, Korean Society of Environmental Engineers
}

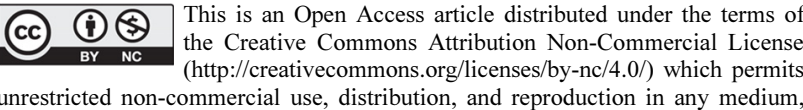
unrestricted non-commercial use, distribution, and reproduction in any medium, provided the original work is properly cited. 


\title{
연구논문
}

\section{STOAT 시뮬레이터를 이용한 MLE공정 질산화 개선에 대한 연구}

\author{
김태욱 $^{1 \odot} \cdot$ 조선주 $^{1 \odot} \cdot$ 권성현 $^{2 \odot} \cdot$ 조대철 $^{1+\oplus}$
}

'순천향대학교 에너지환경공학과

2경상국립대학교 해양환경공학과

목적: 질소제거공정은 수환경 보존 측면에서 매우 중요한 공정이다. 그 가운데 MLE 공정은 변형이 많고 운전 상 노련한 경험이 필요하기 때문에 최적화가 어려웠다. 본 연구에서는 STOAT 시뮬레이션 프로그램을 사용하여 MLE 공정의 질산화에 대해 정량적으로 분석하였다.

방법: 특히 수온에 따른 질산화 효율저하의 문제점 측면에서 '수온-질산화'의 상관성을 규명하려 시도하였다.

결과 및 토의: 그 결과 수온이 $20^{\circ} \mathrm{C}$ 이상일 경우 $93 \%$ 이상의 질산화율이 관찰되었으며, $15^{\circ} \mathrm{C}$ 이하일 때 급격한 암 모니아성 질소의 질산화 감소가 관찰되었다. 네 가지 모사 중 수온이 가장 낮았던 $10^{\circ} \mathrm{C}$ 에서의 질산화 효율 증가를 위해 세 가지 공정 변수를 한번, 혹은 여러번 적용하였으며(MLSS 증가, DO농도 증가, RAS증가) 이 중 공정 변화 의 단일 적용에서 가장 효율적인 공정 변화는 RAS 유량 증가로 공정 변화를 가하지 않은 $10^{\circ} \mathrm{C}$ 유입수의 암모니아 농도에서 $31 \%$ 더 감소한 암모니아 배출농도를 나타내었다.

결론: 두 가지 이상의 공정 변화를 동시에 적용한 경우, 운전에 소요되는 전력을 고려하면 MLE조 내 폭기량 증가 와 RAS 유량만을 동시에 적용시키는 것이 경제적인 측면에서 효율적이며, 이 경우 유출수 내 암모니아 농도는 아 무런 변화를 가하지 않았을 때 보다 $61.4 \%$ 더 감소하였으며, T-N 농도 감소를 위해서는 MLSS 반송량을 증가시키 는 것이 바람직하다.

주제어: 시뮬레이터, 스토어트, 하수처리, 생물학적처리, 루드작에팅거 공법

\section{1. 서론}

인구 증가와 더불어 산업 다양화의 결과로 오염된 수자원의 발생이 사용이 증가하고 있으며 이에 따라 오염물질 배출에 대한 국가적 규제가 더욱 강화되고 있는 실정이다. 2011년부 터 2019년까지 3 번에 걸친 물환경 보존법의 개정이 이루어졌 으며 그 규제는 2 배 이상 강화되었다.

이러한 변화에 따라 하수처리장에서는 개정된 규제치 이하 농도 조건의 방류수 배출을 위한 적절한 처리방법 도출이 요 구되고 있다. 그러나 운전 중인 하수처리장의 공정을 수정하 여 수처리 방법을 모색하는 것은 운전 부하의 증가나 유출수 의 부적절한 처리 등의 위험성이 따른다. 더구나 pilot 규모에 서 각종 시험을 진행하려면 설비 제작에 비용이 들어가고, 연 구에 사용되는 폐수 성상 재현, 외부온도 제어 등을 일정하게 유지하기 어려워 정확한 실험값을 도출하기 어렵다.

그럼에도 불구하고 하수처리장의 폐수처리 효율 개선에 관한 다양한 연구가 진행되었다. 2005년, Ryu 등근 M-DEPHANOX 공정에서 수리학적 체류시간 변화에 따른 질소제거 특성에
관한 연구를 진행한 한편, $\mathrm{Yu}$ 등은 2015년 수질 개선을 위해 시설 확장을 하지 않고 공정 운전인자 조절을 통해 $\mathrm{A}_{2} \mathrm{O}$ 공정 효율을 개선하는 시뮬레이션에 관한 연구를 진행하였다. 또한 Kim 등이이 2012년 발표한 연구에서 컴퓨터 시뮬레이션을 통해 MLE공정 내 Swing조를 무산소 조건으로 운전 시 호기성 조건 일 때 보다 더 양질의 처리수를 확보할 수 있다는 점을 밝혀내 었다.

한국의 기후는 계절에 따른 외기온도와 수온의 변화가 크 다. 질소제거에 작용하는 미생물들은 수온에 따라 활동성이 저하될 수 있고 이는 수처리 공정에서 질소제거 효율을 저하 시키는 원인이 된다. 이에 관련하여 Kim 등은 실제 하수처리 장 운전 데이터를 분석해 수온 변화에 따른 MLE 공정 질산화 -탈질 연구)를 진행하였다. 위 연구는 계절 변화에 따른 수온 변화에 관한 경향을 제시하였다.

수처리 과정에는 수온 외의 여러 조건을 고려해 수처리 방 식을 탄력적으로 운전할 수밖에 없기 때문에 수온과 질산화, 질소제거 사이의 상관관계를 명확히 밝혀내기 어렵다. 이러한 문제를 해결하기 위한 연구에는 하수처리장 가상 운전 시뮬레 
이션 프로그램이 몇 가지 사용될 수 있다. 그 중 수처리 관련 대표적 시뮬레이션 프로그램으로는 BIOWIN과 GPS-X가 거 론된다. 국내에서도 Hong 등이 2011년 발표한 MBR 공법의 생물학적 질소 및 인 제거 평갇에 관한 논문의 시뮬레이션 기반은 BIOWIN이었으며, Kim 등이 2019년 발표한 적정 연 계처리부하량 분석() 논문에서는 GPS-X를 시뮬레이션 설계 프로그램으로 채택하였다. 이처럼 현재 사용되는 시뮬레이션 프로그램의 경우 기본적 하수처리장 설계부터 고도처리를 위 한 화학처리 등, 거의 대부분의 하수처리 방식을 설계하고 평 가할 수 있다. 하지만 위 두 프로그램의 경우 프로그램 사용을 위한 라이센스 비용이 $\$ 10,000$ 이상을 호가한다는 단점을 가 지고 있다.

이번 연구에서는 위와 같은 설계 기능과 인자를 갖춘 무료 소프트웨어인 STOAT (Sewage Treatment and Operation Analysis Over Time)를 사용하였다. STOAT는 미국 Water Research Center에서 개발·배포한 수처리 공정 모사 프로그램이다. 이 프로그램은 2000년 초반에 개발되었으며, $\mathrm{WRc}$ 자체 개발한 활성 슬러지 시뮬레이션 모델인 ASAL Model부터 침전조 내 하수 슬러지의 침강 거동을 모사하는 SSED Model 등을 내장한 거의 모든 하수처리 공정을 설계 및 시뮬레이션 할 수 있는 프로그램이다.

외국 학술지에 이 프로그램을 사용한 논문 여러 편이 게재 되었다. Hassan 등은 STOAT를 이용하여 SBR WWTP를 모델 링한 후, 수리학적 부하에 대비한 수처리 방식에 대해 연국) 하였다. 또한 $\mathrm{Gao}$ 등은 2016년 랴오닝성의 하수처리장 운전 및 관리의 시뮬레이션 ${ }^{8)}$ 을 STOAT로 진행하는 한편, Wang 등은 산화구 공법의 모델링과 $\mathrm{COD}$ 제거 성능의 모상에 에 STOAT를 사용하였으며 그들의 논문에서는 STOAT가 활용도 가 높으며 신뢰할 수 있는 프로그램이라 언급하였다.

본 연구에서는 STOAT simulation 프로그램을 이용하여 MLE 공정의 질산화와 유입수 수온 사이의 상관관계 파악 및 이를 활용한 적절한 질산화와 질소제거 공정 방식에 대해 모 사를 진행하였고, 이를 통해 STOAT 시뮬레이터의 활용성을 제고하고자 하였다.

\section{2. 본론}

\section{1. 연구 이론}

본 연구에서는 BOD제거와 질산화 및 질소제거 시뮬레이션 을 위해 ASAL5A 모델식을 사용하였다. ASAL Model은 G. L. Jones의 활성슬러지공정 내에서 증식하는 박테리아 성장에 관한 수학적 모델 ${ }^{10)}$ 과 A. L. Downing의 Monod kinetics ${ }^{11)}$ 에 기반하여, 활성슬러지 공정에서 일어나는 질산화를 연구한 내 용 등을 수정하여 개발되었다.

Modified Ludzack Ettinger (MLE) 공법은 기존에 사용되던 활성슬러지 공법을 변형한 공법이다. 단일 폭기조로 구성된

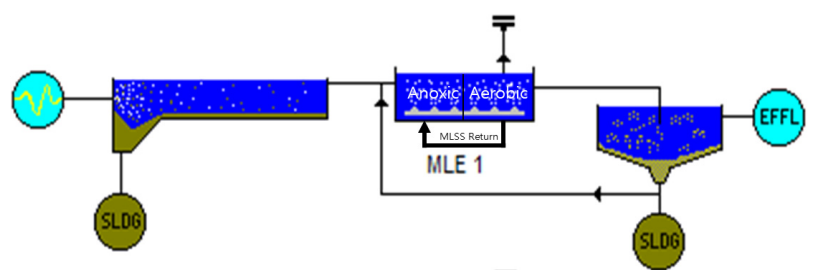

Fig. 1. Various MLE processes with different operation conditions; SLDG: sludge; EFFL: effluents.

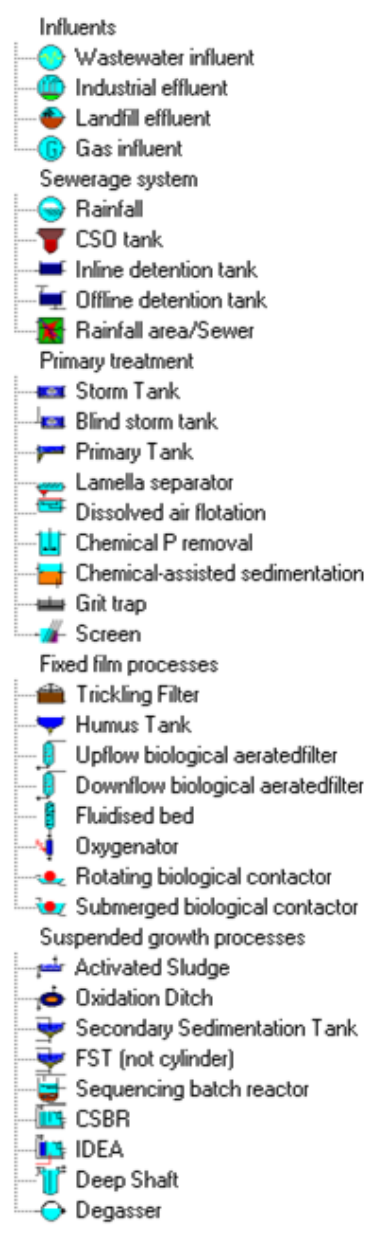

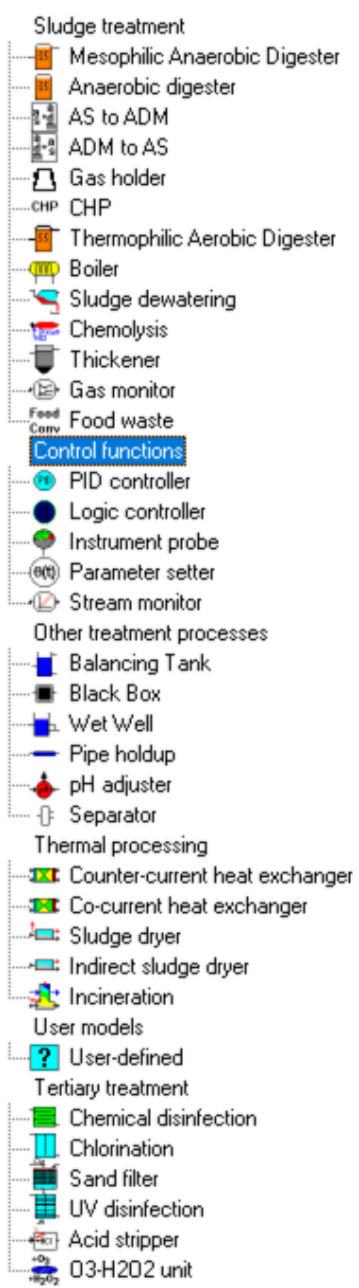

Fig. 2. STOAT program design objects.

활성슬러지법과는 달리 MLE공정은 폭기조를 두 개의 구획으 로 나누어 전단을 무산소조, 후단을 호기성조로 사용한다. 시 험할 공정은 Fig. 1과 같이 배치하였고 각 공정의 layout에 사 용될 기호 및 아이콘을 Fig.2에 나타내었다. 4가지 수온의 유 입수 내 오염물질 농도는 동일하게 설정되어 있으며 공정의 침전지와 폭기조 크기 등의 조건 또한 동일하게 설정하였다. 유입수의 수온은 $25^{\circ} \mathrm{C}, 20^{\circ} \mathrm{C}, 15^{\circ} \mathrm{C}, 10^{\circ} \mathrm{C}$ 로 설정하였다. 유출 수의 암모니아 농도가 얼마나 변하였는지를 확인하는 방법으 로 수온 변화에 따른 질산화 정도를 평가하였다.

Autotroph (독립영양 미생물)와 Heterotroph (종속영양 미생 
물)의 농도는 각 $100 \mathrm{mg} / \mathrm{L}, 1000 \mathrm{mg} / \mathrm{L}$ 로 설정하였다. 이 미생 물의 증식은 프로그램에 입력된 연산을 따르게 되며, 시간에 따른 미생물 총량의 변화는 연산식에 포함된 영양물질의 농도, DO (Dissolved oxygen)농도 등의 인자에 의해 결정된다.

MLE공정을 거치고 2차 침전지로 넘어가는 처리수에는 일 정량의 미생물이 포함되며, MLE공정으로 반송되는 RAS flow 내 포함 미생물 및 MLE조 내에서 증식·존재하는 미생물 의 작용을 통해 MLE조 내에서 다시 질산화가 이루어진다. 여기서 온도 저하나 다른 조건에 의해 계산 과정에 미생물이 충분하지 못할 때에는 질산화 및 탈질의 효율이 저하되며 이 는 최종 유출수의 농도 그래프에 반영되어 나타난다.

먼저, 공정에 변화나 추가적 미생물 공급이 없어도 독립영 양 미생물과 종속영양 미생물이 일정하게 유지되며, 질산화 및 탈질이 가장 양호하게 진행되는 정상상태 조건의 기준을 잡았다. 이 조건은 총괄산소전달계수 $\mathrm{K}_{\mathrm{L}} \mathrm{a}$ 값 2-40 $\mathrm{h}^{-1}, \mathrm{DO}$ 농 도 $4 \mathrm{mg} / \mathrm{L}$, MLSS (Mixed liquor suspended solids)반송량 400 $\mathrm{m}^{3} \mathrm{~h}$, 수온 $20^{\circ} \mathrm{C}$ 이다. 그 후 앞서 언급한 공정변수들을 절반으 로 줄여 유출수 내 오염물질의 농도가 소폭 증가하고 수처리 의 결과가 양호하지 못한 경우의 조건을 공정에 가하였으며 관련 내용은 연구방법에서 설명하기로 한다.

\section{2. 연구 방법}

유입수는 주문진 하수처리장 ${ }^{12)}$ 의 일반 현황 데이터를 참고 하여 농도를 선정하였다. 시뮬레이션에 사용된 유입수의 데이 터는 아래 Table 1 과 같다. 유입수의 조건이 동일한 상태에서 수온이 각 $25^{\circ} \mathrm{C}, 20^{\circ} \mathrm{C}, 15^{\circ} \mathrm{C}, 10^{\circ} \mathrm{C}$ 일 때 동일한 공정을 거친 후 배출된 처리수의 암모니아와 질산염의 농도 분석을 통해 온도와 질산화 및 질소제거 사이의 영향을 확인하였다.

먼저 Table2에 나타난 것처럼 처리수 내 오염물질 농도가 정상상태로 출력되는 이상적(ideal condition) 조건의 공정을 설계한 후 이 조건에서 MLSS 반송량, $\mathrm{K}_{\mathrm{L}}$ a 값과 $\mathrm{DO}$ 농도, 슬러지 반송량을 감소시켰다. 이어서 유입 암모니아의 농도가 $41 \mathrm{mg} / \mathrm{L}$ 일 때 유입수의 수온을 $25^{\circ} \mathrm{C}, 20^{\circ} \mathrm{C}, 15^{\circ} \mathrm{C}, 10^{\circ} \mathrm{C}$ 로 변화를 주어 수온에 따른 질산화의 특성에 대해 모사하였다. 위 모사에서 얻어진 결과값을 기반으로, 낮은 수온에서 질산 화 및 질소제거가 비교적 덜 된 경우의 공정 운전방식(슬러지 반송량 및 내부 반송량, $\mathrm{K}_{\mathrm{L}} \mathrm{a}$ 와 $\mathrm{DO}$ 값 변경)에 변화를 가한 7 가

Table 1. Concentration of virtual inlet wastewater data.

\begin{tabular}{cc} 
Flow $\left(\mathrm{m}^{3} /\right.$ day) & 200 \\
Soluble BOD $(\mathrm{mg} / \mathrm{L})$ & 150 \\
\hline Particulate BOD $(\mathrm{mg} / \mathrm{L})$ & 90 \\
\hline Volatile solids $(\mathrm{mg} / \mathrm{L})$ & 180 \\
\hline Non volatile solids $(\mathrm{mg} / \mathrm{L})$ & 60 \\
\hline Ammonia $(\mathrm{mg} / \mathrm{L})$ & 41 \\
\hline Soluble Phosphate & 13 \\
\hline
\end{tabular}

Table 2. Process parameter settings for different operation conditions.

\begin{tabular}{cccc} 
& $\begin{array}{c}\text { Ideal } \\
\text { condition }\end{array}$ & $\begin{array}{c}\text { Normal } \\
\text { condition }\end{array}$ & $\begin{array}{c}\text { mod 1-7 set } \\
\text { condition }\end{array}$ \\
\hline K La range $(1 / \mathrm{h})$ & $2-40$ & $2-20$ & $2-40$ \\
\hline DL set point $(\mathrm{mg} / \mathrm{L})$ & 4 & 2 & 4 \\
\hline RAS return inflow $\left(\mathrm{m}^{3} / \mathrm{h}\right)$ & 400 & 200 & 400 \\
\hline
\end{tabular}

지 modified case (이하 mod)를 통해 배출수 내 암모니아와 T-N의 농도가 적정수준까지 하락하는 조건을 모색한다.

질소제거 공정에서는 무산소성 상태 조건을 충족하기 위해 무산소조의 $\mathrm{K}_{\mathrm{L}} \mathrm{a}$ 값과 $\mathrm{DO}$ 농도를 0 으로 설정하였으며, 호기조 의 경우 $\mathrm{K}_{\mathrm{L}} \mathrm{a}$ 값의 범위를 $2-20 \mathrm{~h}^{-1}$, DO 설정 농도를 $2 \mathrm{mg} / \mathrm{L}$ 로 설정하였다. 총괄산소전달계수 $\mathrm{K}_{\mathrm{L}} \mathrm{a}$ 는 시간 당 공급할 수 있는 산소의 양을 뜻하는 상수이며 $\mathrm{DO}$ 는 물 속에 녹아있는 산소의 양을 의미하는 값이다. $\mathrm{DO}$ 값을 증가시킨다는 것은 호기조에 공급되는 공기의 양이 늘어 용존되는 산소의 양이 증가함을 뜻하며 $\mathrm{K}_{\mathrm{L}} \mathrm{a}$ 의 증가는 용존산소 증가에 따른 미생물 호흡량의 증가를 의미한다. 호기조에서 무산소조로 반송되는 MLSS 반 송량은 기본 $200 \mathrm{~m}^{3} / \mathrm{h}$ 로 설정하였으며, 유출수의 질산화가 양 호하지 못한 케이스의 경우에는 반송량을 $400 \mathrm{~m}^{3} / \mathrm{h}$ 까지 증가 시켰다.

1 차 침전지의 규모는 전체 부피 $2,000 \mathrm{~m}^{3}$ 이며 침전지의 수 표면적은 $500 \mathrm{~m}^{2}$, 깊이는 $4 \mathrm{~m}$ 로 설정하였다. 침전지의 규모는 네 개의 모델에 모두 동일하게 설정되었다. 다음으로 MLE조 는 총 부피가 $1,600 \mathrm{~m}^{3}$ 이며, $1: 1$ 의 규모로 분할된 2 개의 구획 을 가지고 있다. 전단의 상태는 무산소 상태를 설정하기 위한 설정값이 적용되어 있으며, 후단은 호기성 상태로 설정하기 위해 $\mathrm{DO}$ 농도와 산소전달계수 값을 설정하였다. MLE조의 운 전 조건에 대한 값은 Table 3과 같다. 2차 침전지는 $500 \mathrm{~m}^{2}$ 의 수면적과 $4 \mathrm{~m}$ 의 깊이로 설계되었으며 앞선 공정을 거친 유입 수의 유입구는 $3 \mathrm{~m}$ 에 설치되었다.

Table 3. Running conditions for a normal MLE process run condition.

\begin{tabular}{ccc} 
Volume distribution & $\begin{array}{c}\text { Stage 1 } \\
\text { (anoxic) }\end{array}$ & $\begin{array}{c}\text { Stage 2 } \\
\text { (aerobic) }\end{array}$ \\
\hline Feed distribution & 0.5 & 0.5 \\
\hline Return activated sludge distribution & 1 & 0 \\
\hline Minimum KLa $(1 / \mathrm{h})$ & 0 & 0 \\
\hline Maximum KLa $(1 / \mathrm{h})$ & 0 & 2 \\
\hline Dissolved oxygen set point $(\mathrm{mg} / \mathrm{L})$ & 0 & 20 \\
\hline MLSS return flow $\left(\mathrm{m}^{3} / \mathrm{h}\right)$ & 0 & 200 \\
\hline RAS inflow $\left(\mathrm{m}^{3} / \mathrm{h}\right)$ & 80 & 0 \\
\hline
\end{tabular}


Table 4. The concentration of contaminants in the effluent.

\begin{tabular}{|c|c|c|c|c|c|c|}
\hline & Temperature & Total SS & Total BOD & Ammonia & Nitrate & $\mathrm{T}-\mathrm{N}$ \\
\hline \multirow{5}{*}{$\begin{array}{l}\text { Mean } \\
(\mathrm{mg} / \mathrm{L})\end{array}$} & Ideal & 6.23 & 3.98 & 0.59 & 7.09 & 7.68 \\
\hline & $25^{\circ} \mathrm{C}$ & 4.79 & 3 & 2.5 & 15.24 & 17.73 \\
\hline & $20^{\circ} \mathrm{C}$ & 4.79 & 3.21 & 1.31 & 15.82 & 17.13 \\
\hline & $15^{\circ} \mathrm{C}$ & 4.78 & 5.03 & 4.66 & 14.46 & 19.12 \\
\hline & $10^{\circ} \mathrm{C}$ & 4.78 & 7.1 & 10.07 & 12.18 & 22.25 \\
\hline \multirow{5}{*}{$\begin{array}{l}\text { Total emission mass } \\
\qquad(\mathrm{kg})\end{array}$} & Ideal & 408.40 & 261.00 & 38.43 & 464.64 & 503.07 \\
\hline & $25^{\circ} \mathrm{C}$ & 313.34 & 196.24 & 163.27 & 996.62 & $1,159.89$ \\
\hline & $20^{\circ} \mathrm{C}$ & 313.10 & 210.20 & 85.36 & $1,034.95$ & $1,120.31$ \\
\hline & $15^{\circ} \mathrm{C}$ & 312.68 & 329.31 & 304.95 & 945.56 & $1,250.50$ \\
\hline & $10^{\circ} \mathrm{C}$ & 312.56 & 464.63 & 658.49 & 796.91 & $1,455.40$ \\
\hline
\end{tabular}

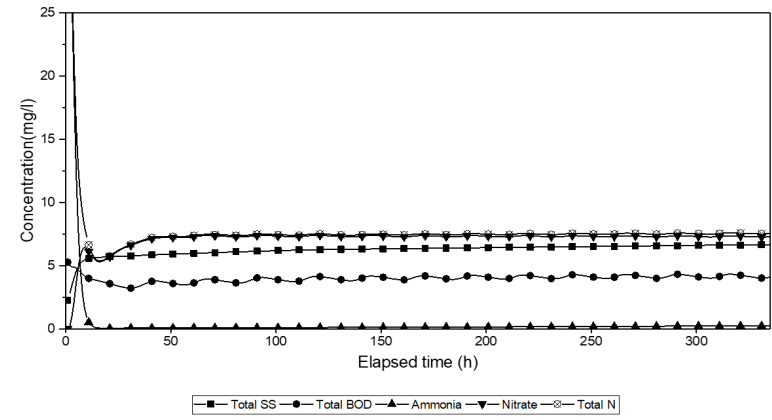

Fig. 3. Concentration profile of contaminants in effluents of ideal condition.

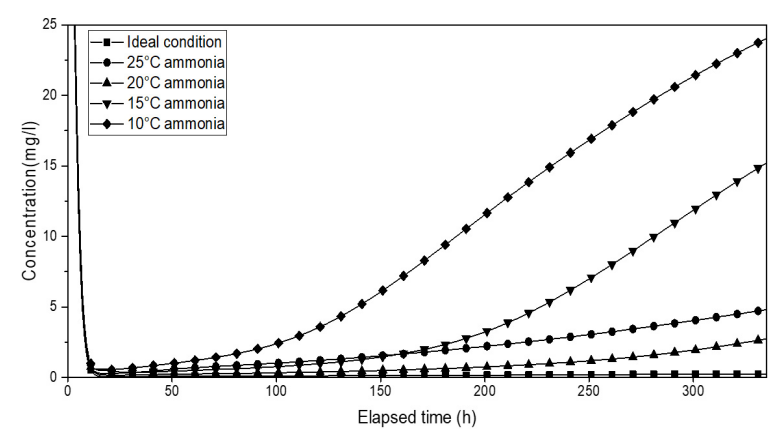

Fig. 4. Ammonia concentration changes in effluent with different inlet wastewater temperatures.

\section{3. 결론 및 고찰}

\section{1. 시뮬레이션 결과}

본 연구에서는 하수처리장에 유입된 유입수의 온도와 질산 화의 상관관계를 관련 연산을 내장한 시뮬레이터를 통해 계 산 하였고, 그 결과를 토대로 질산화 및 질소제거 효율 개선 을 위한 방안에 대해 연구하였다. 시뮬레이션의 시나리오는 다음과 같다. 먼저 질소가 가장 이상적으로 제거되는 조건을 설정한 후 봄, 여름 늦가을, 겨울에 하수처리장에 유입되는 하수의 온도를 각각 $20^{\circ} \mathrm{C}, 25^{\circ} \mathrm{C}, 15^{\circ} \mathrm{C}, 10^{\circ} \mathrm{C}$ 로 설정하고 이후 이루어지는 모든 공정의 과정은 동일하게 설정한다. 시뮬레

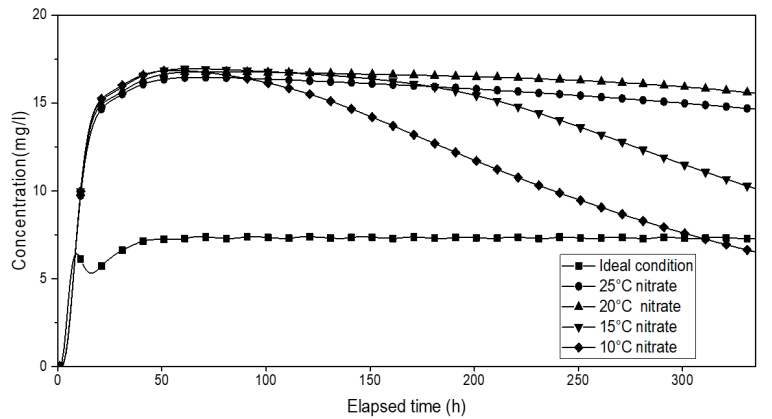

Fig. 5. Nitrate concentration changes in effluent with different inlet wastewater temperatures.

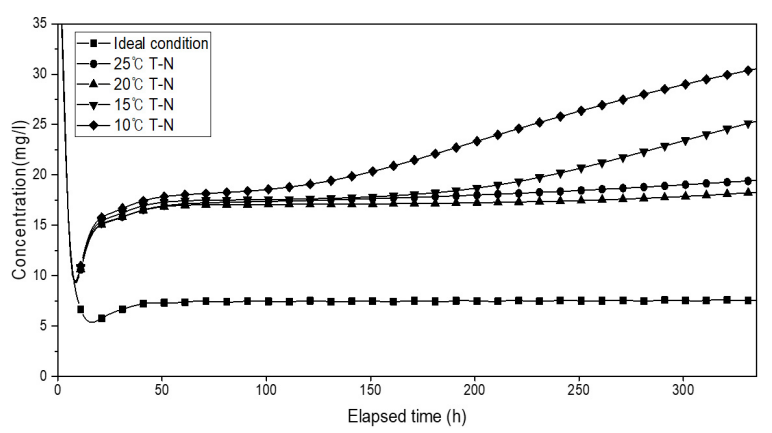

Fig. 6. T-N concentration changes in effluent with different inlet wastewater temperatures.

이션 기간 동안 하수처리장 내에 추가적인 미생물 공급이나 온수 공급, 하수 예열 등의 과정을 거치지 않은 유입수가 처 리되는 과정을 모사한다. 일정 시간이 지남에 따라 폭기조 내 미생물의 농도가 바뀌게 되고, 그에 따른 유출수 내 오염 물질 농도 변화를 통해 수온과 MLE 공정 사이의 상관관계를 파악한다.

유입수의 처리 결과가 정상상태인 Ideal 조건과 Table 1의 조건을 적용한 유입수 수온 변화에 따른 시뮬레이션 결과와 그래프는 Table 4와 Fig. 3-6에 나타나 있다.

Total SS와 Total BOD는 이상적인 조건을 제외한 모든 온도 조건에서 약 $4 \mathrm{mg} / \mathrm{L}$ 내외의 농도로 배출되었다. 이 결과에 
따르면 슬러지에 서식하는 종속영양 미생물은 수온에 큰 영향 을 받지 않으며 유기물을 분해한다.

유출수 내 암모니아 농도 결과는 수온 변화에 크게 영향을 받는 것으로 나타났다. 335 시간 동안 유입된 암모니아의 총량 은 2,680 kg으로 계산되었으며, 배출된 암모니아 총량을 유입 된 암모니아 총량으로 나누어 계산한 각 온도에 따른 암모니 아 질산화율은 이상적인 조건에서 $98.56 \%, 25^{\circ} \mathrm{C}$ 에서 $93.9 \%$, $20^{\circ} \mathrm{C}$ 에서 $96.8 \%, 15^{\circ} \mathrm{C}$ 에서 $88.6 \%, 10^{\circ} \mathrm{C}$ 에서 $75.4 \%$ 로 계산되 었다. 이상적 조건을 제외했을 때 유입된 암모니아의 질산화 율은 유입수 수온이 $20^{\circ} \mathrm{C}$ 일 때 가장 높았으며 수온이 $10^{\circ} \mathrm{C}$ 일 때 가장 낮게 나타났다. Table5에는 각 온도에서 폭기조 내 존재하는 미생물의 평균 농도값이 나와 있다. 수온이 $25^{\circ} \mathrm{C}$ 일 때 보다 $20^{\circ} \mathrm{C}$ 일 미생물의 농도가 더 높게 나타났으며 미생 물의 양이 많은 $20^{\circ} \mathrm{C}$ 에서 더 양호한 질산화가 일어난 것으로 보인다.

Fig.4와 Table 4에 나타난 것처럼, 수온이 $20^{\circ} \mathrm{C}$ 일 경우에 유출수 내 평균 암모니아 농도는 $1.31 \mathrm{mg} / \mathrm{L}$ 로 나타났으며 335 시간의 시뮬레이션 기간동안 유출수 농도가 $5 \mathrm{mg} / \mathrm{L}$ 를 넘지 않았다. 수온이 $25^{\circ} \mathrm{C}$ 인 경우도 유출수 내 평균 암모니아 농도 는 $2.5 \mathrm{mg} / \mathrm{L}$ 로 나타났으며 시뮬레이션 기간 내 유출수에 포함 된 최고 암모니아 농도는 $4.81 \mathrm{mg} / \mathrm{L}$ 로 비교적 양호한 수치를 보였다.

수온이 $15^{\circ} \mathrm{C}$ 이하로 내려가면 유출수 내 암모니아 농도가 비교적 높게 나타났다. 수온이 $15^{\circ} \mathrm{C}$ 였을 때의 유출수 내 암모 니아 평균 농도는 $4.66 \mathrm{mg} / \mathrm{L}$ 로 나타났으며 수온이 $10^{\circ} \mathrm{C}$ 인 경 우에는 $10.07 \mathrm{mg} / \mathrm{L}$ 로 $20^{\circ} \mathrm{C}$ 의 유출수 내 암모니아 농도보다 약 7.6배 높은 수치를 보였다. 또한, 유입수의 수온이 $15^{\circ} \mathrm{C}$ 인 경우 시뮬레이션 시간이 284 시간 경과하였을 때 $10 \mathrm{mg} / \mathrm{L}$ 의 암모니아 유출 농도를 보이며 질산화 효율이 악화되는 그래프 를 보였으며 수온이 $10^{\circ} \mathrm{C}$ 인 경우에는 시뮬레이션이 189 시간 경과했을 무렵부터 유출수 내 암모니아 농도가 $10 \mathrm{mg} / \mathrm{L}$ 이상 으로 나타났다.

앞서 언급한 것처럼, 공정에는 추가적인 미생물의 유입이 없다. MLE 공정을 거친 유입수는 2차 침전지를 거쳐 배출수 로 취급되어 계산된다. 이때 공정을 거친 처리수 이동 과정에 서 MLE조 내에 존재하는 독립영양 미생물이 2차 침전지로 유출되며, MLE조 내 독립영양 미생물의 농도는 미생물 증식 에 관한 계산에 의해 결정된다. 수온이 $20^{\circ} \mathrm{C}$ 이상인 경우의 연산에서는 미생물 증식이 충분이 이루어지는 것으로 계산이 되지만 $15^{\circ} \mathrm{C}$ 이하의 낮은 수온의 연산에서는 미생물 증식이 충분히 일어나지 않는다. 독립영양 미생물은 종속영양 미생물 에 비해 미생물의 증식 속도가 느릴 뿐 아니라 활발한 증식의 조건을 맞춰주는 것 또한 매우 까다롭다. 이와 같은 다양한 이유로 낮은 수온을 유입수로 설정한 MLE 공정 내 독립영양 미생물 농도가 낮아지게 되었으며, MLE 공정에서 암모니아 의 질산화가 충분하지 않은 독립영양 미생물 농도에 의존해
Table 5. Averaged bacterial concentrations in aeration tank.

\begin{tabular}{ccc} 
& $\begin{array}{c}\text { Heterotroph } \\
\text { concentration }(\mathrm{mg} / \mathrm{L})\end{array}$ & $\begin{array}{c}\text { Autotroph } \\
\text { concentration }(\mathrm{mg} / \mathrm{L})\end{array}$ \\
\hline $25^{\circ} \mathrm{C}$ & $1,024.3$ & 109.4 \\
\hline $20^{\circ} \mathrm{C}$ & $1,272.4$ & 124.0 \\
\hline $15^{\circ} \mathrm{C}$ & 860.8 & 76.4 \\
\hline $10^{\circ} \mathrm{C}$ & 567.3 & 54.2 \\
\hline
\end{tabular}

계산된다. 이 결과로 유출수 내 질산화되지 못한 암모니아가 배출되어 암모니아의 농도가 높아진 것이다. 이번 모사 결과 에 의하면, 앞서 설정한 하수처리장의 설계 조건에서 유입수 내에 존재하는 암모니아의 충분한 질산화를 위해서는 수온이 $20^{\circ} \mathrm{C}$ 이상 되어야 하며, 이 경우에도 운전 시간이 350 시간이 경과하였을 때에는 질산화 미생물을 첨가해주거나 RAS의 유 량을 증가시켜야 한다는 결과가 도출되었다.

유출수 내 질산염의 경우에는 수온이 $25^{\circ} \mathrm{C}, 20^{\circ} \mathrm{C}, 15^{\circ} \mathrm{C}, 1$ $0^{\circ} \mathrm{C}$ 인 경우 평균 질산염 농도는 각각 $15.24 \mathrm{mg} / \mathrm{L}, 15.82$ $\mathrm{mg} / \mathrm{L}, 14.46 \mathrm{mg} / \mathrm{L}, 12.18 \mathrm{mg} / \mathrm{L}$ 로 나타났다. Fig.9에 나타난 것처럼 수온이 $25^{\circ} \mathrm{C}, 20^{\circ} \mathrm{C}$ 일 때의 질산염 그래프는 정상상태 에 가까운 그래프를 보였으며 질산화 또한 정상적으로 이루어 지는 것으로 나타났다.

수온이 $20^{\circ} \mathrm{C}$ 인 경우의 시뮬레이션 최종 데이터인 335 시간 지점에서 배출 암모니아 농도가 $2.74 \mathrm{mg} / \mathrm{L}$ 일 때 배출 질산염 농도는 $15.55 \mathrm{mg} / \mathrm{L}$ 로 계산되었다. 유입수의 수온이 $15^{\circ} \mathrm{C}$ 이 하로 낮아질수록 질산염의 배출 농도도 낮아지며 유입수의 수온이 $10^{\circ} \mathrm{C}$ 일 때의 최종 유출수 질산염 농도는 $6.52 \mathrm{mg} / \mathrm{L}$ 로 계산되었다. 유입수 수온이 낮을 때 유출수의 질산염 농도가 낮게 계산된 이유는 낮은 수온으로 인해 미생물의 활동성이 저하된다는 계산 하에 유입된 암모니아가 충분히 질산화되지 않은 결과이다. Fig.6에 나타난 것처럼 $25^{\circ} \mathrm{C}, 20^{\circ} \mathrm{C}$ 조건에서 는 $50 \%$ 이상의 T-N 제거 효율을 보여주었으나 $15^{\circ} \mathrm{C}$ 이하에 서는 T-N의 제거 효율이 $50 \%$ 이하로 감소하고 있다.

한편, 유출수 내 암모니아 농도가 가장 높았던 유입수 수온 $10^{\circ} \mathrm{C}$ 의 공정에 공정 변화를 가하여 암모니아의 질산화 방안 에 대해 모색하였다.

이 변화에는 Table4에 나타난 것처럼 MLE조 내 MLSS반 송, 폭기량 증가 $\left(\mathrm{K}_{\mathrm{L}}\right.$ 값과 $\mathrm{DO}$ 농도 설정치 조정), 2 차 침전지 에서 MLE조로 반송되는 RAS량 조절 등이 포함되며, Table 6에 나타난 것처럼 각 변화를 개별적으로 적용한 3 가지 케이 스 $(\bmod 1-3)$ 와 $\bmod 1-3$ 을 중첩으로 적용한 케이스 $(\bmod 4-7)$ 를 통해 MLE공정의 질산화 및 질소제거 효율에 관해 모사하 였다. 탈질 효율은 앞선 수온 변화에 따른 시뮬레이션의 결과 로 파악되었기 때문에 이번 공정 변화의 효율 평가는 암모니 아 농도를 중심으로 파악하며 질소제거의 전제인 질산화가 얼마나 잘 일어나는지에 중점을 두어 분석하였다.

Mod 1-7의 시뮬레이션 결과는 Table7과 Fig.7에 나타나 
Table 6. Applied process changes.

\begin{tabular}{|c|c|c|c|}
\hline & $\begin{array}{l}\text { Return MLSS flow change } \\
\left(200 \mathrm{~m}^{3} / \mathrm{h} \rightarrow 400 \mathrm{~m}^{3} / \mathrm{h}\right)\end{array}$ & $\begin{array}{c}\text { Aeration flow change } \\
\left(\mathrm{K}_{\mathrm{L}} \mathrm{2} 2-20 / \mathrm{h}^{-1} \rightarrow 2-40 / \mathrm{h}^{-1}\right. \\
\text { DO set point } 2 \mathrm{mg} / \mathrm{L} \rightarrow 4 \mathrm{mg} / \mathrm{L})\end{array}$ & $\begin{array}{l}\text { RAS flow change } \\
\left(50 \mathrm{~m}^{3} / \mathrm{h} \rightarrow 80 \mathrm{~m}^{3} / \mathrm{h}\right)\end{array}$ \\
\hline $\bmod 1$ & $\bullet$ & & \\
\hline $\bmod 2$ & & 0 & \\
\hline $\bmod 3$ & & & - \\
\hline $\bmod 4$ & 0 & 0 & \\
\hline $\bmod 5$ & 0 & & 0 \\
\hline $\bmod 6$ & & 0 & 0 \\
\hline $\bmod 7$ & 0 & 0 & 0 \\
\hline
\end{tabular}

(a)

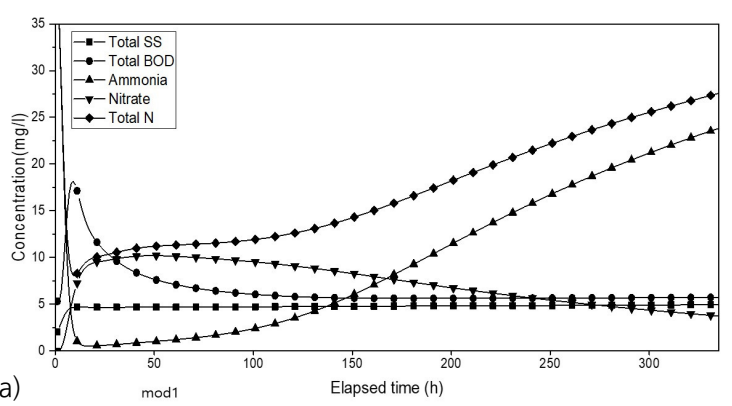

(c)
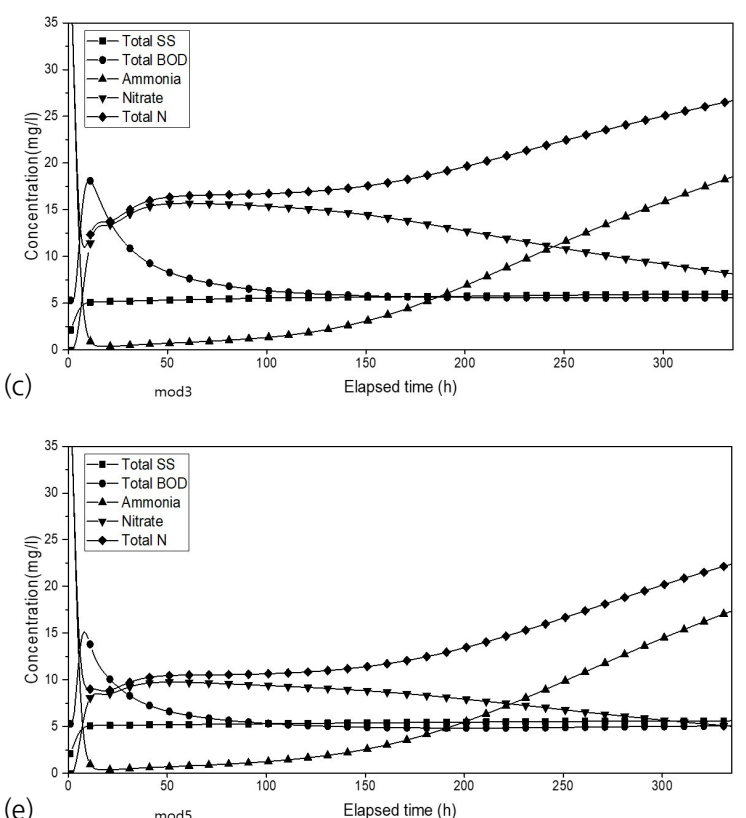

(e)

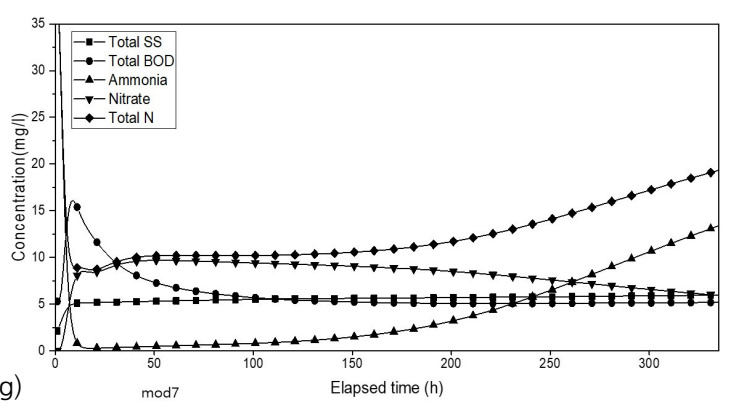

(b)

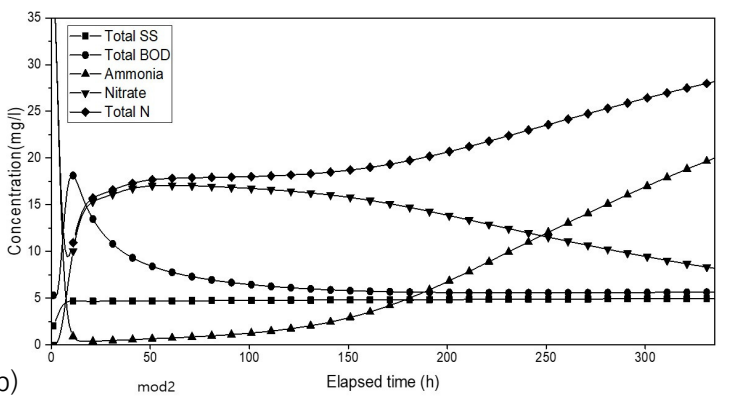

(d)
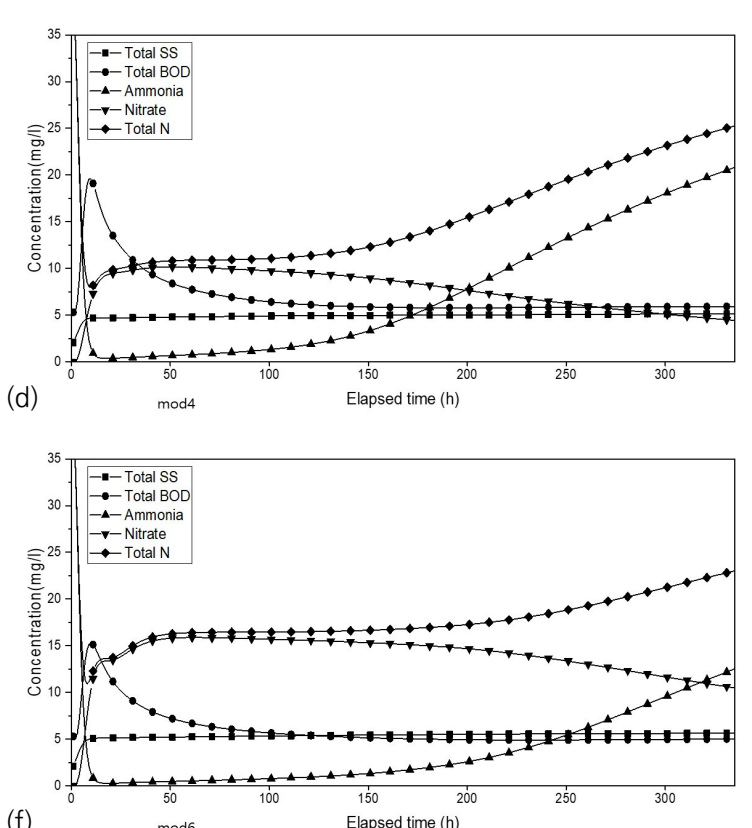

$\bmod 6$

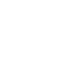

Fig. 7. Concentration profile of contaminants in effluents of mod 1-7. 
Table 7. Final effluent compositions for 7 cases of process change.

\begin{tabular}{|c|c|c|c|c|c|c|}
\hline & Name & Total SS & Total BOD & Ammonia & Nitrate & $\mathrm{T}-\mathrm{N}$ \\
\hline \multirow{7}{*}{$\begin{array}{l}\text { Mean } \\
(\mathrm{mg} / \mathrm{L})\end{array}$} & $\bmod 1$ & 3.94 & 3.94 & 8.51 & 5.36 & 17.18 \\
\hline & $\bmod 2$ & 3.94 & 3.95 & 7.28 & 5.61 & 20.64 \\
\hline & $\bmod 3$ & 4.82 & 4.12 & 4.00 & 7.52 & 19.47 \\
\hline & $\bmod 4$ & 3.94 & 3.95 & 7.28 & 5.61 & 15.46 \\
\hline & $\bmod 5$ & 4.57 & 3.92 & 3.56 & 6.17 & 13.94 \\
\hline & $\bmod 6$ & 4.81 & 4.11 & 3.22 & 7.72 & 17.73 \\
\hline & $\bmod 7$ & 4.80 & 4.07 & 3.21 & 6.03 & 12.53 \\
\hline \multirow{7}{*}{$\begin{array}{l}\text { Total emission mass } \\
\qquad(\mathrm{kg})\end{array}$} & $\bmod 1$ & 257.97 & 257.80 & 556.75 & 350.65 & $1,123.9$ \\
\hline & $\bmod 2$ & 257.48 & 258.06 & 475.92 & 367.18 & $1,349.8$ \\
\hline & $\bmod 3$ & 315.65 & 269.73 & 262.37 & 492.89 & $1,275.8$ \\
\hline & $\bmod 4$ & 257.48 & 258.06 & 475.92 & 367.18 & $1,013.2$ \\
\hline & $\bmod 5$ & 298.95 & 256.16 & 232.54 & 403.44 & 911.9 \\
\hline & $\bmod 6$ & 315.44 & 269.25 & 211.27 & 505.49 & $1,159.5$ \\
\hline & $\bmod 7$ & 314.74 & 266.55 & 210.12 & 395.25 & 820.9 \\
\hline
\end{tabular}

있으며 유출수 내 암모니아 농도는 Fig. 8에, T-N의 농도는 Fig.9에 나타나있다. 먼저, MLSS 반송량을 유량의 $200 \mathrm{~m}^{3} / \mathrm{h}$ 에서 $400 \mathrm{~m}^{3} / \mathrm{h}$ 로 변경한 $\bmod 1$ 의 유출수 내 암모니아 평균 농도는 $9.99 \mathrm{mg} / \mathrm{L}$ 로 공정 변화를 가하지 않았을 경우보다 암 모니아 농도가 $0.79 \%$ 소폭 감소하였다. 다음으로 $\bmod 2$ 설 정에서는 폭기량을 증가시킨 것으로 가정하여 $\mathrm{K}_{\mathrm{L}} \mathrm{a}$ 값과 $\mathrm{DO}$

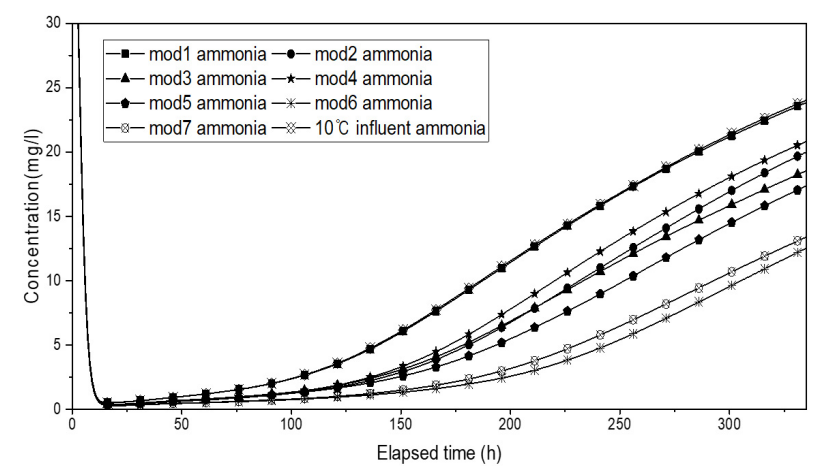

Fig. 8. Ammonia in the effluents with a period of time for 7 mods.

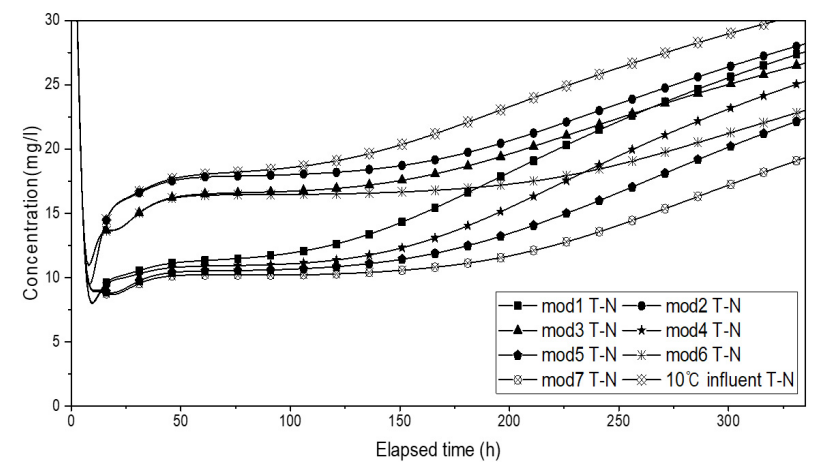

Fig. 9. T-N in the effluents with a period of time for 7 mods.
설정값을 증가시켰다. $\mathrm{STOAT}$ 에서 $\mathrm{K}_{\mathrm{L}} \mathrm{a}$ 값과 $\mathrm{DO}$ 는 개별적 계 산 인자이며 폭기량 증가에 따른 산소농도 증가를 모사하기 위해 두 인자를 증가시킨 것으로 설정하였다. $\bmod 2$ 의 경우 의 배출수 내 암모니아 농도는 $7.14 \mathrm{mg} / \mathrm{L}$ 로 변화를 가하지 않은 경우보다 암모니아 농도가 $29.1 \%$ 더 감소하였다. 가장 큰 변화를 보인 $\bmod 3$ (RAS유량 증가)의 유출수 내 암모니 아 농도는 $6.93 \mathrm{mg} / \mathrm{L}$ 로 공정 변화를 가하지 않은 수온 $10^{\circ} \mathrm{C}$ 의 유출수 내 암모니아 농도보다 $31.2 \%$ 감소하여 세 개의 공 정 변화 시뮬레이션 중 가장 높은 암모니아 배출 감소를 보 였다.

질산화 활성화를 통한 질소제거 효율 증가를 위해 위 $\bmod$ 1-3을 중첩적으로 적용한 $\bmod 4-7$ 의 복합공정 모사 결과도 위와 비슷한 양상을 나타내었다. RAS 유량을 증가시킨 모든 케이스에서 더 많은 암모니아 배출이 감소하였으며 특히 폭기 량과 RAS 유량을 동시에 증가시킨 $\bmod 6$ 의 유출수 내 암모 니아 농도는 공정 변화를 가하지 않았을 경우보다 $61.4 \%$ 더 감소하였다. $\bmod 1-3$ 을 모두 중첩 적용한 경우의 유출수 내 평균 암모니아 농도는 $4.34 \mathrm{mg} / \mathrm{L}$ 로 $\bmod 6$ 보다 소폭 높은 수 치를 나타내었다.

모사 결과의 시사점은 다음과 같다. 호기조 내 $\mathrm{DO}$ 농도와 산소전달계수 $\mathrm{K}_{\mathrm{L}} \mathrm{a}$ 를 증가시키면 독립영양 미생물인 질산화 균의 활동성이 증가되어 질산화 반응 및 미생물의 증식이 소 폭 증가되고, 결과적으로 질산화에 어느정도 도움을 줄 수 있 는 것으로 나타났다.

반송 슬러지는 MLE 공정의 전단인 무산소 조로 유입된다. 유입된 슬러지 및 유입액은 공정 흐름을 따라 다시 호기성조 로 이동하게 된다. 이와 같은 과정에서 호기조 내에는 독립영 양 미생물이 유입되며, 이 재유입된 미생물은 질산화 작용을 촉진시킨다. 2 차 침전지로 유출된 독립영양 미생물을 함유한 슬러지를 폭기조로 반송함으로써, 미생물을 재공급하고 이를 
통해 질산화를 촉진하는 RAS 반송 방식이 수온이 낮은 유입 수의 질산화에 가장 효율적인 방식으로 나타났다.

$\bmod 1,2,3$ 을 모두 적용한 $\bmod 7$ 의 유출수 내 T-N 농도는 $12.53 \mathrm{mg} / \mathrm{L}$ 로 모든 $\bmod$ 케이스 중 가장 낮은 농도를 보였 다. 폭기조 내 MLSS 반송이 $\bmod 6$ 과 $\bmod 7$ 공정의 차이인 데, MLSS 반송을 통해 질산화된 폐액이 무산소조에서 탈질 이 되었다. MLSS 반송은 질산화에 큰 영향을 주지는 못 하 지만, 폐액 내 T-N 제거에는 효과적인 공정임을 보여주고 있다.

\section{2. 결론}

본 모사에서는 수처리 시뮬레이터인 STOAT를 활용하여 수온에 따른 질산화 효율에 대해 평가하였다. $25^{\circ} \mathrm{C}, 20^{\circ} \mathrm{C}$, $15^{\circ} \mathrm{C}, 10^{\circ} \mathrm{C}$ 모든 온도 조건의 시뮬레이션 결과의 유출수 내 $\mathrm{TSS}$ 와 TBOD 농도는 $5 \mathrm{mg} / \mathrm{L}$ 미만으로 양호한 처리 결과를 보였다.

수온이 $25^{\circ} \mathrm{C}, 20^{\circ} \mathrm{C}$ 에서는 유출수 내 평균 암모니아 농도는 각 $2.5 \mathrm{mg} / \mathrm{L}, 1.31 \mathrm{mg} / \mathrm{L}$ 로 충분한 질산화가 일어나 양호한 암모니아 배출값을 보였으나 수온이 $15^{\circ} \mathrm{C}, 10^{\circ} \mathrm{C}$ 로 감소하였 을 때에는 유출수 내 암모니아 농도는 $4.66 \mathrm{mg} / \mathrm{L}, 10.07 \mathrm{mg} / \mathrm{L}$ 로, 악화된 질산화 양상을 보였다.

질산화가 가장 적게 일어난 수온이 $10^{\circ} \mathrm{C}$ 인 경우의 질산화 효율을 증가시키기 위한 공정 변화 결과에서는, MLE 공정 내부 MLSS 반송량을 증가시켰을 때의 암모니아 배출량은 아 무런 변화를 가하지 않은 유출수 수온 $10^{\circ} \mathrm{C}$ 일 때 대비 $0.79 \%$ 감소하였다. 폭기량을 변화한 경우(폭기조 내 DO 농도와 $\mathrm{K}_{\mathrm{L}} \mathrm{a}$ 값을 증가시킨 경우) 암모니아 농도는 $29.1 \%$ 감소하였고, 2 차 침전지에서 $\mathrm{MLE}$ 공정으로 반송되는 RAS의 유량을 $50 \mathrm{~m}^{3} / \mathrm{h}$ 에서 $80 \mathrm{~m}^{3} / \mathrm{h}$ 로 증가시켰을 때에는 암모니아가 $31.2 \%$ 감소하 여 가장 큰 변화량을 보였다.

또한 질산화 효율 증가를 위해 MLE공정 내 MLSS 반송량 증가, 폭기량 변화, RAS 유량 증가를 중첩적으로 적용하여 시뮬레이션을 진행하였다. 세 가지 공정을 모두 적용한 경우 아무런 공정 변화를 가하지 않았을 경우에 비해 유출수 내 암모니아 배출량이 $56.9 \%$ 감소하였으며, 폭기량과 RAS유량 을 동시에 증가한 경우 $61.4 \%, \mathrm{MLE}$ 공정 내 MLSS 반송량과 폭기량을 동시에 증가시켰을 때 $23 \%$ 감소하였다.

겨울철 수온이 낮을 경우 RAS 유량을 증가시키는 방법이 가장 효율적으로 질산화 효율을 증가시킬 수 있는 방법이며, MLSS 반송량 증가는 질산염의 탈질에 효과적인 방법이다. 유출수의 T-N 값이 높은 경우에는 MLSS 반송량을 증가시켜 야 하며 질산화가 양호하지 않을 시 폭기량을 증가시키거나 RAS 유량을 증가를 통한 미생물의 재공급과 같은 방식을 적 용해야 한다.

\section{References}

1. H. D. Ryu, S. I. Lee, Comparison of removal characteristics of organic matter, nitrogen and phosphorus in suspended-growth and hybrid processes with hydraulic retention time, J. Korean Soc. Environ. Eng., 28(1), 15-25(2006).

2. H. S. Yoo, B. H. LEE, A Study on adjustment of operational factor in $\mathrm{A}_{2} \mathrm{O}$ process, J. Korea Org. Res. Rec. Associ., 23(3), 33-41(2015).

3. K. H. Kim, J. H. Lee, T. K. Kim, J. Y. Choi, Review of sewage treatment plant design standard \& study for process optimizing in MLE using simulation program, in Proceedings of 2012 Joint Academic Conference, Korean Society on Water Environment - Korean Society of Water \&Wastewater, pp. 494-495(2012).

4. K. H. Kim, J. Y. Hyun, J. Y. Choi, H. S. Lee, A Study on nitrification and denitrification in MLE process, in Proceedings of 2012 Joint Academic Conference, Korean Society on Water Environment - Korean Society of Water \&Wastewater, pp. 498-499(2012).

5. H. S. Chul, B. H. Lee, Evaluation of biological nitrogen and phosphorus removal in MBRs (Membrane Bioreactors) by computer simulation, J. Korean Soc. Urb. Environ., 11(1), 9-17(2011).

6. S. J. Kim, J. W. Lee, K. I. Gil, Analysis of proper linked treatment load using GPS-X simulation, J. Wet. Res., 21(3), 244-250(2019).

7. H. H. Hassan, A. M. Ragheb., Modelling of an SBR WWTP to enhance the performance under hydraulic shock load using STOAT software, Int. J. Civil Eng. Archit., 13, 704-714(2019).

8. Y. N. Gao, X. Z. Liu, R. X. Zhang, J. J. Shan, Operation and management of liaoning waste water treatment plants by STOAT simulation, in Proceedings of 2016 International Conference on Mechatronics, Manufacturing and Materials Engineering, China, pp. 04019(2016).

9. Weiyi Wang, Chen Shi, Junfeng Yang, Ming Zeng, Zongbiao Dai and Zongpeng Zhang, Modelling performance of oxidation ditch in wastewater treatment plant by STOAT software, in Proceedings of IOP Conference Series Earth and Environmental Science, England, pp. 300(2019).

10. G. L. Jones, Bacterial growth kinetics: measurement and significance in the activated-sludge process, Water Res., 7(10), 1475-1492(1973).

11. A. L. Downing, Biological processes of importance in the treatment and disposal of industrial wastewaters, Water pollution research laboratory(1967).

12. Korea Enviroment Corporation, Jumunjin Sewage Treatment Facility, https://www.konetic.or.kr/infodb/new_planbuild_view .asp? cate $=1 \&$ sort $=$ A\&sort $2=\mathrm{A} 2 \&$ gotopage $=10 \&$ unique_num =3986, $\operatorname{March}(2021)$. 


\section{Declaration of Competing Interest}

The authors declare that they have no known competing financial interests or personal relationships that could have appeared to influence the work reported in this paper.

\section{Authors and Contribution Statement}

\section{Taewook Kim}

Department of Energy \& Environmental Engineering, Soonchunhyang University, Master's degree candidate, ORCID 다 0000-0001-7639 -5035: Data curation, Data analysis, Methodology, Supervision, Validation, Visualization, Writing - original draft, Writing - review and editing.

\section{Sunjoo Cho}

Department of Energy \& Environmental Engineering, Soonchunhyang University, Master's degree candidate, ORCID (다 0000-0003-4363 -7944: Data curation, Resources.

\section{Sung-Hyun Kwon}

Department of Marine Environmental Engineering, Gyeongsang National University, Professor ORCiD(1) 0000-0001-5803-2003: Conceptualization, Project administration.

\section{Daechul Cho}

Department of Energy \& Environmental Engineering, Soonchunhyang University, Professor, ORCID 다 0000-0002-0286-6743: Conceptualization, Data analysis, Methodology, Project administration, Supervision, Validation, Writing - review and editing. 